\title{
Huge Renal Angiomyolipoma with Life-threatening Bleeding into Itself Spontaneously
}

Kendi İcine Spontan Kanayarak Hayatı Tehdit Eden Büyük Renal Anjiyomiyolipom

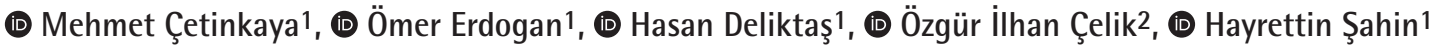 \\ ${ }^{1}$ Muğla Sıtkı Koçman University Faculty of Medicine, Department of Urology, Muğla, Turkiye \\ 2 Muğla Sıtkı Koçman University Faculty of Medicine, Department of Pathology, Muğla, Turkiye
}

\begin{abstract}
Renal angiomyolipoma (R-AML) is one of the most common benign neoplasms of the kidney. It is usually asymptomatic and rarely becomes symptomatic. Management of R-AML is still controversial. Generally, follow-up is enough for the management of the disease but rarely, lifethreatening complications may develop. Here, we would like to present a case of huge R-AML with life-threatening bleeding with literature review. Keywords: Benign renal neoplasm, Nephrectomy, Angiomyolipoma
\end{abstract}

Öz

Renal anjiyomiyolipom (R-AML) böbreğin sık görülen benign tümörlerindendir. Genellikle asemptomatik olup nadiren semptomatik hale gelirler. Günümüzde halen R-AML'lerin nasıl tedavi edilmesi gerektiği açıklık kazanmamıştır. Genel yaklaşım bu hastalarda izlemdir fakat nadir de olsa hayatı tehdit edebilmektedir. Bu makalede devasal boyuta ulaşıp spontan kanayarak hayatı tehdit eden R-AML olgusunu ve uygulanan tedaviyi literatür eşliğinde sunduk.

Anahtar Kelimeler: Benign böbrek tümörü, Nefrektomi, Anjiyomiyolipom

\section{Introduction}

Renal angiomyolipoma (R-AML) is a benign mesenchymal neoplasm composed of smooth muscle cells, adipose tissue and thick-walled blood vessels in different compositions. It is usually asymptomatic and found incidentally by routine imaging techniques and rarely becomes symptomatic. The prevalence of R-AML in the general population is between $0.3 \%$ and $3 \%$ and females are 4 times more at risk than males $(1,2)$. It develops sporadically in $80 \%$ of cases and might be a clinical sign of tuberous sclerosis.

We would like to present a patient with giant R-AML which was complicated by life-threatening bleeding into itself spontaneously.

\section{Case Presentation}

A 59-year-old male patient presented to the emergency department with abdominal distension, swelling, pain and confusion. There was no trauma or any anticoagulant drug use in the past medical history. Skin color was pale and a solid mass was palpated in the right upper and lower quadrant of the abdomen. His blood pressure was $100 / 60 \mathrm{mmHg}$, heart rate - 108 beats/min, hemoglobin $(\mathrm{Hb})-7.1 \mathrm{gr} / \mathrm{dL}$, hematocrit $(\mathrm{Htc})$ - 24\%, platelet count - 124000 , urea $-45 \mathrm{mg} / \mathrm{dL}$ and creatinine was $1.5 \mathrm{mg} / \mathrm{dL}$.

Computed tomography (CT) of the abdomen revealed a $30 \times 25$ $\mathrm{cm}$ massive lesion originating from the hilum of the right kidney and extending inferiorly and laterally to the right lower quadrant of the abdomen, and including vascular parts in fat

Correspondence: Mehmet Çetinkaya MD, Muğla Sıtkı Koçman University Faculty of Medicine, Department of Urology, Muğla, Turkiye

Phone: +90 5053117005 E-mail: drmemoly@yahoo.com ORCID-ID: orcid.org/0000-0001-8395-646X

Received: 10.03 .2017 Accepted: 25.04 .2017

Poster Statement: 12 $2^{\text {nd }}$ National Congress of Urooncology Antalya (18-22 November 2015)

Cite this article as: Çetinkaya M, Erdoğan Ö, Deliktaş H, Çelik Öi, Şahin H. Huge Renal Angiomyolipoma with Life-threatening Bleeding into Itself Spontaneously. J Urol Surg 2018;5(2):116-119.

๑Copyright 2018 by the Association of Urological Surgery / Journal of Urological Surgery published by Galenos Publishing House. 
tissue. It was considered as a bleeding AML. One hour after the admission to the emergency department, $\mathrm{Hb}$ dropped to $6.4 \mathrm{~g} / \mathrm{dL}$ and Htc dropped to 20.9\%. The patient underwent emergency laparotomy due to suspicion of bleeding and the exploration revealed bleeding giant AML originating from the right kidney. Right radical nephrectomy was performed with administering 8 units of erythrocyte suspension and 2 units of fresh frozen plasma. After transferring him to the intensive care unit for 5 days, he completely recovered and was discharged from the hospital pathology showed that the lesion was composed of adipose tissue with proliferative vascular structures and fusiform-cheroot-shaped cells (Figure 1). Immunohistochemical staining for smooth muscle actin showed that fusiform-cherootshaped cells were smooth muscle fibers (Figure 2). These areas were also subjected to human melanoma black-45 staining. Vascular structures were stained with CD34. The diagnosis was AML based on the findings.

Written informed consent was obtained from the patient.

\section{Discussion}

The term "angiomyolipoma" was first used by Morgan et al. (3) for defining a renal tumor composed of smooth muscle and adipose tissue with different proportions. AML arises sporadically in $80 \%$ and accompanies tuberous sclerosis in $20 \%$ of cases. Sporadic cases usually seen in females aged $40-70$ years and mostly manifest as a large, single and unilateral massive lesion (4). It may also be related with von Hippel-Lindau disease, von Recklinghausen syndrome and polycystic kidney disease (5).

In our case, we evaluated the central nervous system, skin and retina and we did not find any sign related with tuberous sclerosis. Therefore, our case was diagnosed as sporadic AML.

The most important complications seen in patients with AML are retroperitoneal hemorrhage, hematuria and renal failure caused by tumor compression. Sporadic AML is usually asymptomatic and found incidentally as a single mass by renal visualization techniques (6). In our case, the diameter of the mass was 30 centimeters, and this is one of the largest tumors reported in the literature. Renal cell carcinoma, oncocytoma or any other metastatic cancers must be considered in the differential diagnosis. The classical presentation of AML on ultrasonography (USG) is hyperechoic lesion with acoustic ghosting $(2,6,7)$. The most echogenic tumors in all renal tumor types seen on USG are AMLs. CT is the most commonly used imaging technique for the diagnosis of AML $(7,8)$. It is difficult to diagnose AMLs
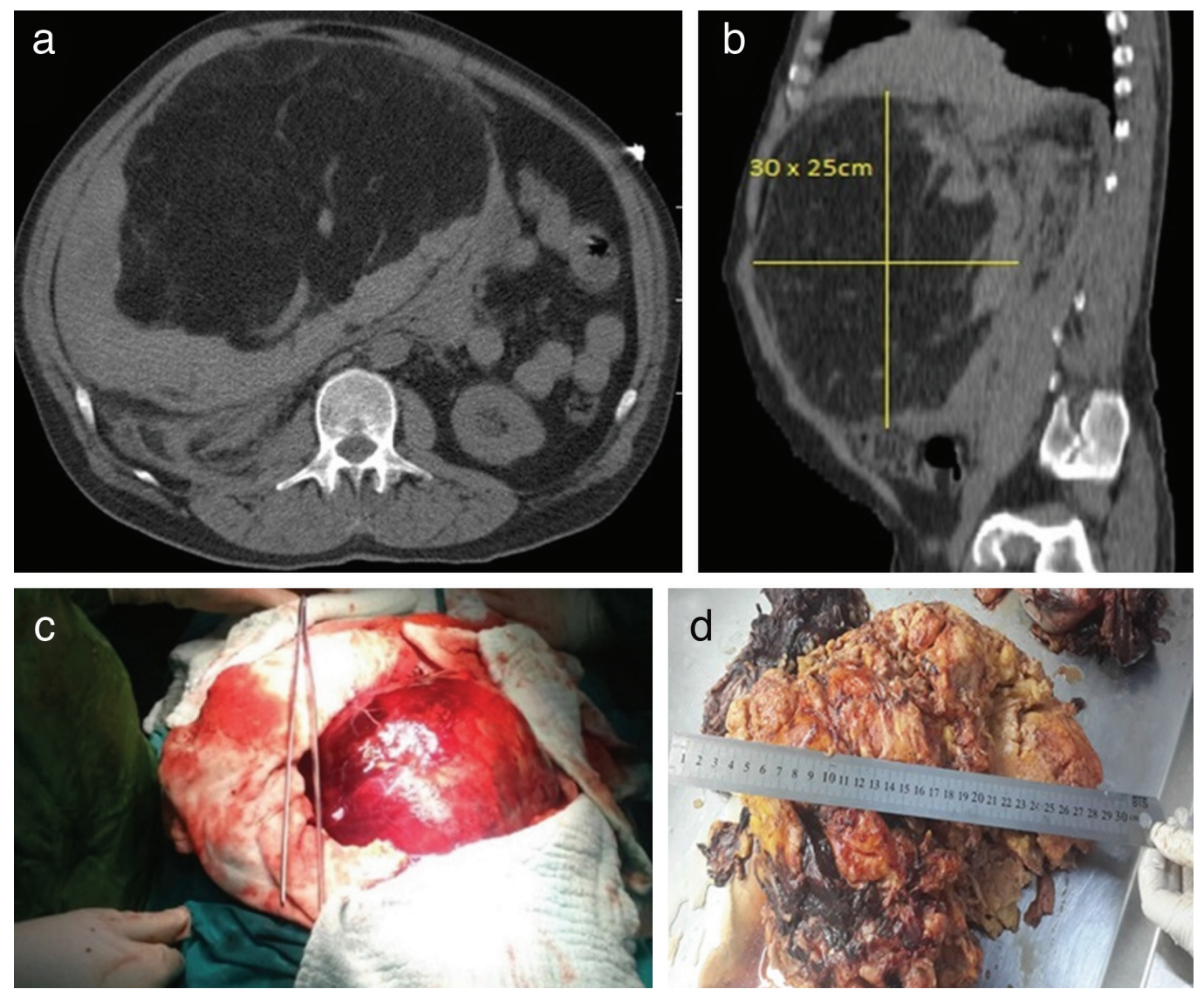

Figure 1. (a) Giant pathological mass on the transverse cross section computed tomographic scans, (b) mass size on sagittal sections, $30 \times 25 \mathrm{~cm}$ (c) intraoperative photograph of angiomyolipoma, (d) specimen showing renal angiomyolipoma 

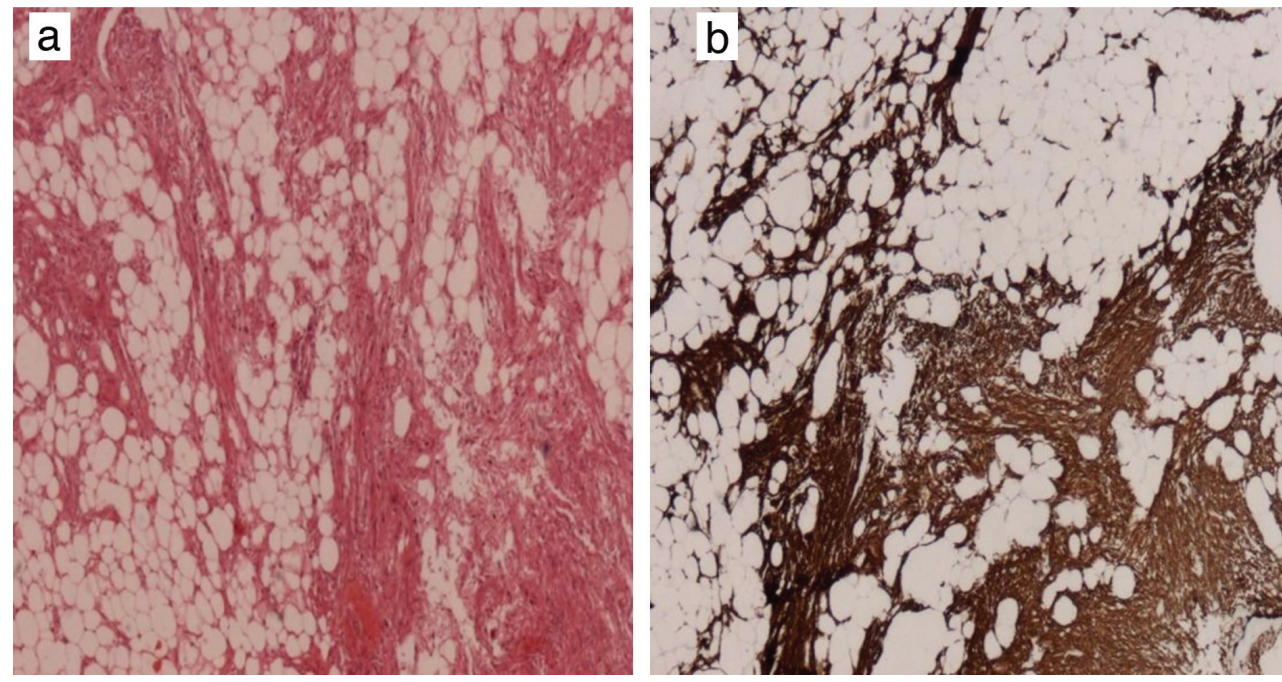

Figure 2. (a) Angiomyolipoma composed of lipocytes, smooth muscle bundles and vascular structures (hematoxylin and eosin 40x), (b) smooth muscle bundles of angiomyolipoma positive for smooth muscle actin (smooth muscle actin 40x)

with a small amount of fat using CT or USG (8). In our case, we observed a mass lesion composed of adipose density with vascular structures on $\mathrm{CT}$ and it was diagnosed as AML.

The treatment of renal AML is still controversial. For asymptomatic small lesions, follow-up is recommended. Surgical treatment options for AML are radical or partial nephrectomy, selective arterial embolization and ablative methods including cryoablation and radiofrequency ablation. Moreover, a new medical treatment, mechanistic target of rapamycin (mTOR) inhibitors are used for AML related with tuberous sclerosis. Oesterling et al. (9) suggested prophylactic surgery for renal AMLs larger than $4 \mathrm{~cm}$, concomitant with aneurysms larger than $5 \mathrm{~mm}$ and AMLs with excessive vascularization due to spontaneous bleeding risk. Selective renal artery embolization or total nephrectomy may be an appropriate option for tumors which are inappropriate for nephron-sparing surgery because of tumor size and location. Following with USG once a year is enough for AMLs which are asymptomatic and smaller than $4 \mathrm{~cm}$ (10). Follow-up intervals must be shorter in pregnant patients and those receiving estrogen therapy because there is increased spontaneous rupture risk of AML due to increased estrogen and progesterone receptor expression, maternal circulation and intraabdominal pressure (11). Surgery may be suggested before pregnancy for patients with AML larger than $4 \mathrm{~cm}$ or a history of bleeding AML (12).

According to the European Association of Urology guidelines, the most favorable approach to asymptomatic renal AMLs is active follow-up. The first option is selective arterial embolization when any intervention is needed. When the option is surgery, most patients can be treated with nephron-sparing surgery but in some exceptions complete nephrectomy might be a choice. Furthermore, surgery may be delayed if tumor size decreases by mTOR inhibitors (everolimus and sirolimus) (13). In our case, we performed total nephrectomy instead of nephron-sparing surgery because the mass was huge and there was excessive perioperative blood loss.

In fact, our patient received the diagnosis of AML 5 years ago in another clinic but he was not followed. He would not have spontaneous bleeding if the patient had appropriate treatment for 5 years. Prophylactic surgery is the option for AMLs larger than $4 \mathrm{~cm}$ or concomitant with aneurysms larger than $5 \mathrm{~mm}$ because of the spontaneous bleeding risk (9). We believe that our patient's hemorrhage was due to an aneurysm rupture because there was no history of trauma or anticoagulant medication use.

As a result, we believe that huge AMLs should be electively treated before the symptoms occur.

\section{Ethics}

Informed Consent: Written informed consent was obtained from the patient.

Peer-review: Externally peer-reviewed.

\section{Authorship Contributions}

Surgical and Medical Practices: M.Ç., H.D., Ö.E., Concept: M.Ç., H.Ş., Ö.I.Ç., Design: M.Ç., Ö.E., H.D., H.Ş., Data Collection or Processing: M.Ç., H.Ş., Ö.E., Literature Search: M.Ç., Ö.E., Writing: M.Ç., Ö.E.

Conflict of Interest: No conflict of interest was declared by the authors.

Financial Disclosure: The authors declared that this study received no financial support. 


\section{References}

1. Steiner MS, Goldman SM, Fishman EK, Marshall FF. The Natural-History of Renal Angiomyolipoma. J Urology 1993;150:1782-1786.

2. Nelson $\mathrm{CP}$, Sanda MG. Contemporary diagnosis and management of renal angiomyolipoma. J Urol 2002;168:1315-1325.

3. Morgan GS, Straumfjord JV, Hall EJ. Angiomyolipoma of the kidney. J Urol 1951;65:525-527.

4. Tamboli $\mathrm{P}, \mathrm{Ro} \mathrm{JY}$, Amin MB, Ligato $\mathrm{S}$, Ayala AG. Benign tumors and tumorlike lesions of the adult kidney part II: Benign mesenchymal and mixed neoplasms, and tumor-like lesions. Adv Anat Pathol 2000;7:47-66.

5. Reuter VE. Renal tumors exhibiting granular cytoplasm. Semin Diagn Pathol 1999:16:135-145.

6. Bissler JJ, Kingswood JC. Renal angiomyolipomata. Kidney Int 2004;66:924934.

7. Halpenny D, Snow A, McNeill G, Torreggiani WC. The radiological diagnosis and treatment of renal angiomyolipoma-current status. Clin Radiol 2010;65:99-108.
8. Kim JK, Kim SH, Jang YJ, Ahn H, Kim CS, Park H, Lee JW, Kim S, Cho KS. Renal angiomyolipoma with minimal fat: Differentiation trom other neoplasms at double-echo chemical shift FLASH MR imaging. Radiology 2006;239:174180.

9. Oesterling JE, Fishman EK, Goldman SM, Marshall FF. The Management of Renal Angiomyolipoma. J Urol 1986;135:1121-1124.

10. Gould Rothberg BE, Grooms MC, Dharnidharka VR. Rapid growth of a kidney angiomyolipoma after initiation of oral contraceptive therapy. Obstet Gynecol 2006;108:734-736.

11. Preece $P$, Mees $B$, Norris $B$, Christie $M$, Wagner $T$, Dundee P. Surgical management of haemorrhaging renal angiomyolipoma in pregnancy. Int $J$ Surg Case Rep 2015;7:89-92.

12. Lopater J, Hartung 0 , Bretelle F, Bastide C. Management of angiomyolipoma vena cava thrombus during pregnancy. Obstet Gynecol 2011;117:440-443.

13. Ljungberg B, Bensalah $K$, Canfield $S$, Dabestani $S$, Hofmann $F$, Hora $M$, Kuczyk MA, Lam T, Marconi L, Merseburger AS, Mulders P, Powles T, Staehler M, Volpe A, Bex A. EAU guidelines on renal cell carcinoma: 2014 update. Eur Urol 2015;67:913-924. 